\title{
Os limites da soberania régia A capitania da Paraíba do Sul entre 1727 e 1730
}

\author{
Ronald Raminelli ${ }^{12}$ \\ Universidade Federal Fluminense - $\mathrm{CNPq}$ - Faperj \\ Niterói - Rio de Janeiro - Brasil
}

O artigo analisa os limites da soberania régia sobre a capitania da Paraíba do Sul a partir dos conflitos entre o donatário da capitania e o governador do Rio de Janeiro. Em 1674, a monarquia portuguesa a concedeu à Casa Asseca, mas o território ficou abandonado e sujeito às ocupações das ordens religiosas e dos criadores de gado. Anos depois, o visconde de Asseca retomou o controle, mas enfrentou forte oposição do governador que a tinha ilegalmente como capitania anexa ao Rio de Janeiro. No embate, nem sempre os opositores se guiaram pelos ditames do poder real. Intensificados entre 1727 e 1730, os abusos e conflitos de jurisdição demonstravam os limites da soberania régia nos confins do Império. $\mathrm{O}$ trabalho ainda destaca as diferenças entre as intervenções régias e os interesses particulares das autoridades providas pela monarquia.

\section{Palaviras-chave}

Soberania - conflitos - administração colonial.

1 Universidade Federal Fluminense - CNPq - Faperj - Niterói - Rio de Janeiro - Brasil

2 Doutorado em História na Universidade de São Paulo (USP). Professor titular em História Moderna no Departamento de História do Instituto de História da Universidade Federal Fluminense (UFF). Contato: rraminelli@uol.com.br. 


\section{The limits of the royal sovereignty The Paraíba do Sul captaincy between 1727 and 1730}

\section{Abstract}

This article analyses the limits of the royal sovereignty in Paraíba do Sul through conflicts between the donatary of the captaincy and the governor of Rio de Janeiro. In 1674, the Portuguese monarchy granted it to the House of Asseca, but the territory was abandoned and subject to the occupations of religious orders, captains, and cattle ranchers. Years later, the viscount of Asseca retook control, but faced strong opposition from the governor who had annexed it illegally to the captaincy of Rio de Janeiro. In this conflict, the rivals were not always guided by the dictates of the Crown. The abuses and conflicts of jurisdiction, intensified between 1727 and 1730, demonstrated the limits of royal sovereignty on the borders of the Empire. Also highlighted in the paper are the differences between royal interventions and the particular interests of the authorities supported by the monarchy.

Sovereignty - conflicts - colonial administration. 
Em janeiro de 1750, Martim Correia de Sá, o quarto visconde de Asseca $(1698-1778)^{3}$, iniciou a redação de suas memórias ${ }^{4}$. Embora curtas e muito econômicas nas descrições e nomeações, o visconde descreveu dia após dia o cotidiano da alta nobreza em Lisboa: suas festas, casamentos e eventos variados. Marcado por datas e autenticado por assinaturas do autor, o diário registrava particularmente os funerais e os necrológicos de figuras ilustres da Corte: titulados, bispos e conselheiros do rei. Vez por outra, o visconde ainda mencionava os credores e a situação financeira vivenciada por sua casa ${ }^{5}$. Os escritos em forma de diário findaram pouco antes do terremoto de Lisboa. $\mathrm{O}$ cataclismo por certo interrompeu o bom e raro hábito do fidalgo que registrava suas impressões sobre a vida nos altos circuitos da cidade.

Em junho de 1753, junto ao irmão frei Salvador Correia, desembargadores e procuradores da Coroa, o visconde assinou a "escritura do contrato de premiação da capitania da Paraíba do Sul”. Na ocasião, degustaram um primoroso refresco de doces, frutas geladas e "sorvetes de diversas castas polidamente servidos". Para além do cardápio e das autoridades, o nobre não forneceu maiores detalhes sobre a cerimônia, tampouco descreveu os motivos para a assinatura do contrato. A data no entanto indica o fim da donataria, o retorno à Coroa da capitania cedida a Salvador Correia de Sá e Benevides e legada a seus filhos em 1674. A resolução pretendia pacificar a região, agitada por décadas pelas disputas de terras e desmandos de todo o tipo. No diário do visconde, as tormentas em Paraíba do Sul simplesmente nunca existiram, embora ele próprio tivesse participação intensa nos conflitos entre 1727 e 1732. A invasão da câmara, prisões e perda da capitania não mereciam registros entre os hábitos cortesãos descritos fartamente pelo quarto visconde.

3 Os nomes e datas referentes aos membros da família Correia de Sá foram consultados em: RHEINGANTZ, Carlos G. Primeiras famílias do Rio de Janeiro (séculos XVI e XVII). Rio de Janeiro: Livraria Brasiliana Editora, 1965-1967. vol. 1, p. 394-395.

4 Arquivo Nacional da Torre do Tombo (ANTT), Manuscritos da Livraria, n. 2652.

5 Sobre o terremoto de Lisboa, ver: MONTEIRO, Nuno G. D. Fosé na sombra de Pombal. Lisboa: Círculo de Leitores, 2008. p. 97-118; SUBTIL, José. O terremoto politico (1755-1759). Lisboa: UAL, 2007. 
A família Correia de Sá sempre manteve vínculos estreitos com o ultramar. O título de visconde originou-se dos feitos heroicos de Salvador Correia de Sá e Benevides (1601-1688) como governador da capitania do Rio de Janeiro, libertador de Angola do domínio holandês e membro do Conselho de Guerra ${ }^{6}$. Seus descendentes preservaram a preponderância nas conquistas e exerceram postos no Estado da Índia e no Brasil. O irmão do quarto visconde, Luís José Correia de Sá, foi governador de Pernambuco (1749-1756), posto mencionado em suas memórias quando dava notícias vindas do Recife. Aliás, do Brasil, a Casa dos Asseca retirava cerca de $1 / 3$ de seus rendimentos, provenientes, sobretudo, de Campos dos Goytacazes ${ }^{7}$. Para imortalizar as vitórias do ilustre antepassado, "construtor do maior navio do mundo", o galeão Padre Eterno, o visconde registrou a comemoração do dia 24 de agosto, data da restauração de Angola, marco na trajetória da casa e do seu ingresso paulatino na alta nobreza lisboeta. A perda da capitania portanto não comprometia o passado de glória, os feitos de seus antepassados no ultramar.

Mesmo combalido por sua expulsão do Rio de Janeiro em $1660^{8}$, ao retornar ao reino, Salvador Correia de Sá e Benevides passou a pleitear mercês para remunerar seus serviços e lealdades aos monarcas da dinastia Bragança. Entre muitos pedidos, solicitou a patente de mestre de campo para seu filho João Correia de Sá e o título de visconde de Asseca para o filho Martim Correia de Sá e Benevides (1639-

6 Sobre a trajetória de Salvador Correia de Sá e Benevides, ver: BOXER, C. R. Salvador de Sá e a luta pelo Brasil e Angola 1602-1686, trad. São Paulo: Companhia Editora Nacional, 1973; NORTON, Luís. A dinastia dos Sás no Brasil. Lisboa: Agência Geral do Ultramar, 1965; ALENCASTRO, Luiz Felipe. Trato dos viventes: formação do Brasil no Atlântico Sul. São Paulo: Companhia das Letras, 2000. p. 199-238.

7 Cálculo a partir dos dados fornecidos por Nuno Monteiro referentes ao ano de 1771; ver: MONTEIRO, Nuno G. A casa e o patrimônio dos grandes portugueses (1750-1832). Tese (Doutorado em História), Universidade de Lisboa, Lisboa, 1995. p. 781.

8 ANTT, Miscelâneas Manuscritas do Convento da Graça, tomo 7D, p. 241; Arquivo Histórico Ultramarino (AHU), Rio de Janeiro, Códice Castro Almeida (CA), doc. 879. Sobre a revolta da cachaça, ver: CAETANO, Antônio Filipe P. Entre a sombra e o sol. A revolta da cachaça e a crise política fluminense. Maceió: Ed. Gráfica, 2009. 
1674), que se tornou o primeiro visconde de Asseca, título criado por d. Afonso VI em janeiro de 1666. O valoroso libertador de Angola também pleiteou a concessão de terras entre as capitanias de Cabo Frio e Espírito Santo 9 . Recebeu então a donataria da capitania da Paraíba do Sul, também denominada Campos dos Goytacazes, com a condição de não somente povoar o litoral e o sertão, mas também difundir o culto divino em nome do senhor. A doação da capitania enriquecia a pessoa benemérita e o Reino, pois quantas mais capitanias povoadas quantos mais navios saiam carregados de açúcar e de outros $\operatorname{produtos}^{10}$.

Datada de 1674, a mercê de doação criava duas capitanias, a maior para o primeiro visconde de Asseca, Martim Correia de Sá, e a segunda para o seu irmão, João Correia de Sá, general do Estreito da Índia. Antes da mercê de doação, as terras e fazendas da família Correia de Sá, localizadas entre Cabo Frio e Espírito Santo, estavam sob a administração do velho Salvador Correia de Sá e Benevides até a sua partida para Lisboa. Depois, as propriedades eram administradas a distância, pois os donatários sempre estiveram ausentes da capitania ${ }^{11}$ : o primeiro residia em Lisboa e o segundo em Ormuz. A mercê, porém, exigia contrapartidas, pois em seis anos os donatários deveriam fundar duas vilas com suas igrejas decentes, cadeia, casas da câmara e dos moradores. "A doação e mercê de juro e herdade para sempre" requeria

9 ANTT, Registo Geral de Mercês (RGM), Mercês de Afonso VI, liv. 9, f. 35v. Encontrei porém na Torre do Tombo a concessão do mesmo título com data de 1675: ANTT, Registo Geral de Mercês (RGM), Mercês de Afonso VI, liv. 17, f. 183v-184v. Vale aqui destacar uma dúvida. A morte do primeiro visconde, segundo Rheingantz, data de 1674, ano da concessão da donataria. A data não é destacada na historiografia e lança dúvida sobre a data do falecimento. RHEINGANTZ, Carlos. Op. Cit., vol. 1, p. 394-395. AHU, Rio de Janeiro, CA, doc. 836; 838; 1258. ANTT, RGM, Mercês (Chancelaria) de D. Afonso VI, liv. 9, f. 35 v.

10 SALDANHA, António Vasconcelos de. As capitanias do Brasil. Lisboa: GNPCDP, 2001. p. 100.

11 De fato, originalmente eram duas capitanias, mas não se fez a demarcação para estabelecer os limites entre ambas. Talvez por esta razão, na documentação posterior, não há menção às duas, mas somente à capitania da Paraíba do Sul. AHU, Rio de Janeiro, CA, doc. 13.348. Sobre a concessão de terras, ver: AHU, Rio de Janeiro, CA, doc. 1258. 
uma vila no porto do mar para segurança das embarcações e outra no sertão para reprimir os insultos dos "gentios bárbaros".

Nomeados de capitão e governador, os donatários podiam indicar ouvidor, com jurisdição e ação de morte natural de escravos e gentios, assim como de peões e cristãos homens livres. Os Correia de Sá estavam proibidos de tomar terras de sesmarias para si, para sua mulher e filhos herdeiros. As antigas sesmarias ficavam preservadas, mas os donatários tinham o controle sobre todas as moendas de água, marinhas de sal e todos os engenhos de qualquer tipo. Na longa carta de doação, direitos e deveres estavam assegurados pelo monarca, que prometia ao visconde e a todos os seus sucessores a preservação da doação para todo o sempre ${ }^{12}$.

A coleta de dízimos e redízimos, e o controle de terras e da justiça estavam entre os principais poderes cedidos. Aliás, a carta de doação criou sobreposições de poderes que se tornaram motivos de cizânia entre os representantes dos viscondes, potentados locais, ordens religiosas, ouvidores e governadores. Em princípio, vale mencionar que os Correia de Sá não passaram a exercer controle jurisdicional sobre território dominado por comunidades indígenas, como o fizeram os donatários do século XVI ${ }^{13}$. Desde o início, enfrentaram a resistência de sesmeiros, beneditinos, jesuítas, criadores de gado e donos de engenhocas, entre outros ${ }^{14}$. De modo exemplar, a intensa e muito bem documentada disputa na capitania da Paraíba do Sul nos serve para

12 A carta de doação está inserida em documentação posterior: AHU, Rio de Janeiro, CA, doc. 13.317. Não localizei a carta original de 1674, mas Feydit a publicou e indicou como fonte o Registro geral da câmara municipal da vila de São Salvador de 1740-1749, f. 183v. FEYDIT, Julio. Subsídios para a história dos Campos dos Goytacazes. Rio de Janeiro: Editora Esquilo, 1979. p. 52-61.

13 SALDANHA, António. Op. Cit., p. 95-104.

14 A bibliografia sobre a capitania entre 1650 e 1750 é bastante reduzida, mas a principal referência é HARRISON, William F. A struggle for land in colonial Brazil. Tese (Doutorado em História), New Mexico University, Novo Mexico, 1970. Vale ainda mencionar algumas referências encontradas nos seguintes estudos: LARA, Sílvia H. Campos da violência. Rio de Janeiro: Paz e Terra, 1988. p. 127-146; LAMEGO, Alberto Ribeiro. O homem e o brejo. Rio de Janeiro: IBGE, 2007. p. 52-85; FARIA, Sheila de Castro. A colônia em movimento. Rio de Janeiro: Nova Fronteira, 1998. p. 27-35. 
avaliar os limites da soberania régia, os conflitos e as jurisdições aos moldes do Antigo Regime.

Na Paraíba do Sul, os embates não se reduziam às contendas entre as elites locais e os representantes dos viscondes, mas entre os últimos, a câmara, as ordens religiosas, os governadores e os ouvidores. Os incidentes se tornaram mais intensos em duas conjunturas. Datado entre 1727 e 1732, o primeiro conflito teve como protagonistas os representantes do donatário e o governador da capitania do Rio de Janeiro, Luís Vahia Monteiro (1724-1732); datado de 1748, o segundo teve envolvimento ativo da câmara e as disputas entre os bandos dos Asseca e do licenciado Manuel Manhães Barreto. O presente artigo pretende inicialmente analisar a honra e os privilégios dos Correia de Sá e em seguida as investidas contra a donataria da capitania da Paraíba do Sul, entre 1674 e 1730. O foco principal da análise centra-se, porém, no conflito entre o governador e o procurador do visconde entre 1727 e 1730 .

No Antigo Regime, a jurisdição era delegada pela Coroa e se exercia poder sobre uma região conforme as determinações da monarquia. Deter a jurisdição nem sempre era deter o total poder de mando sobre o território. Ao contrariar os ditames régios, as autoridades coloniais abusavam da jurisdição, contrariavam as determinações régias e atuavam como autônomos. Assim, um oficial régio não poderia exercer poder contrário às normas de seu regimento, oposto ou alheio às determinações do centro, sem abusar de sua autoridade delegada. No período colonial, nem sempre existiram conflitos de jurisdições, mas conflitos de interesses, de poderes que não raro passavam ao largo das normas régias. Ao vender os postos, o morgado e a capitania, o terceiro visconde de Asseca não exercia a sua jurisdição, mas abusava das doações concedidas pela monarquia.

Os dicionaristas dos Setecentos trataram de forma nebulosa o tema das jurisdições, embora não deixassem de marcar seus vínculos com a norma. Bluteau a entendeu como "um poder que o público concede, e que o bom governo introduziu para decisão das causas. Divide-se em ordinária e delegada". A primeira era perpétua e introduzida por lei enquanto a jurisdição dada para causas particulares era delegada 
e temporal ${ }^{15}$. A definição apresentada por Moraes Silva tem um texto mais confuso, pois a entendeu como: "O poder de conhecer dos casos sujeitos à direção das leis civis, ou eclesiásticas, e de as fazer executar, e aplicar voluntariamente, ou a vontade das partes...". A jurisdição ordinária era necessária e competia aos juízes e magistrados ordinários enquanto a jurisdição delegada voluntária competia aos que tomavam o lugar dos ordinários ${ }^{16}$.

Mais recentemente, Pedro Cardim entendeu jurisdição como manifestação do poder "público" e legítimo, conforme o direito e o justo. Diferenciava-se então das formas de coação baseadas na força ${ }^{17}$. Ao tratar da literatura jurídica do Antigo Regime português, Barbas Homem concebeu jurisdição como um poder de direito público. Ordinariamente tratava sobre temas diversos e circunscritos a um território. Mencionou ainda a jurisdição delegada como poder que o príncipe encarregou de certa causa ou causas. Era portanto excepcional e restrita em relação à jurisdição ordinária. Para o jurista espanhol Luís de Molina, a jurisdição é o poder de dizer o direito determinado pelo rei. Assim, a jurisdição do príncipe se exercia sobre todo o reino e "ninguém pode exercer jurisdição no Reino sem a concessão do príncipe...". O estabelecimento de jurisdições era característica essencial dos reis absolutos por deter a titularidade da jurisdição suprema. $\mathrm{O}$ seu poder criava magistrados, vendia ofícios, concedia nobreza, indultava e mudava sentenças. No entanto, restavam meios para não acatar as determinações régias. Barbas Homem enumerou as quatro causas da injustiça, como razão para a legítima desobediência: as leis promo-

15 BLUTEAU, Raphael. Vocabulario portuguez e latino. Coimbra: Collegio das Artes da Companhia de Jesu, 1728. vol. 4, p. 230.

16 SILVA, Antônio de Moraes. Diccionário da língua portuguesa. Lisboa: Typographia Lacerdina, 1813. vol. 2, p. 195.

17 CARDIM, Pedro. "Administração" e "governo": uma reflexão sobre o vocabulário do Antigo Regime. In: BICALHO, M. F.; FERLINI, V. (org.). Modos de governar. São Paulo: Alameda, 2005. p. 54. 
toras de pecados; a injusta divisão de encargos; as autoridades sem jurisdição; a lei incapaz de promover o bem comum ${ }^{18}$.

$\mathrm{O}$ artigo pretende analisar a obediência à autoridade real, a autonomia dos oficiais régios e os conflitos jurisdicionais. De fato, a análise parte da hipótese de que as disputas se originavam mais do abuso da jurisdição régia do que efetivamente dos conflitos jurisdicionais. Metodologicamente, o discernimento entre abuso e conflito se viabilizava com o cotejo entre as práticas administrativas e as normas estabelecidas pelo Conselho Ultramarino. Aliás, não é possível caracterizar as disputas entre os governadores e donatários sem o conhecimento das respectivas jurisdições. Os conflitos jurisdicionais são muito comentados na historiografia brasileira recente, embora poucos verticalizaram a análise.

Vale mencionar o importante estudo de Vera Acioli que alertou para a dubiedade dos regimentos e da política da Coroa para as disputas entre os oficiais régios, com destaque para as rivalidades entre o governo geral da Bahia e o governador de Pernambuco ${ }^{19}$. No entanto, o estudo não realizou o cotejo entre as práticas administrativas e as normas metropolitanas. Como Acioli, os estudiosos ainda não concederam a devida atenção às normas e se prendem às práticas, rivalidades, sem comprovar se os conflitos eram ou não jurisdicionais.

\section{Os Asseca em Campos dos Goytacazes}

Em 1627, o governador Martim Correia de Sá (1623-1632), antepassado do visconde, atuou como procurador do antigo donatário Gil de Góis e fez doação de carta de sesmaria a sete capitães, moradores

18 HOMEM, António P. Barbas. Fudex Perfectus; função jurisdicional e estatuto judicial em Portugal, 1640-1820. Lisboa: Almedina, 2003. p. 119-130.

19 Em relação aos regimentos, Vera Acioli mencionou: "De qualquer forma, muitas dúvidas sobre a jurisdição nasciam da ambiguidade dos regimentos e das atitudes dúbias ou pouco claras da Coroa”. ACIOLI, Vera Lúcia Costa. Jurisdição e conflito: aspectos da administração colonial. Recife: EdUFPE, 1997. p. 82. Os conflitos de jurisdição são tratados de forma inovadora em tese recente. Infelizmente a pesquisa não se ateve às normas: CHAVES JUNIOR, José Inaldo. As capitanias de Pernambuco e a construção dos territórios e das jurisdições na América portuguesa (século XVIII). Tese (Doutorado em História), UFF, Niterói, 2017. passim. 
do Rio de Janeiro, beneméritos de sua majestade e leais servidores por mais de 20 anos em guerras na mesma capitania, em São Vicente e Cabo Frio ${ }^{20}$. Com aliados indígenas, eles conquistaram terras vazias ou dominadas por forasteiros e inimigos. Nos arredores do Rio e em Cabo Frio seus engenhos e fazendas não dispunham de terras suficientes para criação do gado e eram incapazes de sustentar suas propriedades. Receberam sesmarias para servir a Deus e povoar em proveito da Fazenda de sua majestade, "por razão dos dízimos". Nas terras graciosamente cedidas pela monarquia, os sete capitães construíram currais para criar gado ${ }^{21}$.

Passaram os anos e os descendentes dos sete capitães não cumpriram as exigências e pouco desenvolveram as sesmarias. Lentamente perderam as terras e despertaram a cobiça do governador da capitania do Rio de Janeiro, dos beneditinos e jesuítas ${ }^{22}$. Em 1648, pouco antes da partida para Angola, Salvador Correia de Sá e Benevides promoveu a redistribuição das sesmarias, recorrendo a táticas pouco ortodoxas. A medida trouxe muitas vantagens não só para Salvador, mas também para seus amigos e protegidos, como os jesuítas e os beneditinos. Assim, o velho governador, em 1652, dispunha de sete mil cabeças de gado bovino, setenta cavalos, 150 negros escravos e muitos outros bens ${ }^{23}$. Envolvido em guerras e problemas com a administra-

${ }^{20}$ FRAGOSO, João. A nobreza vive em bandos: a economia política das melhores famílias da terra do Rio de Janeiro, século XVII. Tempo, n. 15, p. 11-36, 2003. Sobre a apropriação do território do Rio de Janeiro e arredores, ver: ABREU, Maurício de. Geografia histórica do Rio de Janeiro (15021700). Rio de Janeiro: Andrea Jakobsson Estúdio e Prefeitura do Rio de Janeiro, 2010. 2 vol.

${ }^{21}$ FEYDIT,Julio. Op. Cit., p. 31; LAMEGO, Alberto. A terra goytacá à luz de documentos inéditos. Paris/ Bruxelas: L'Édition d'Art/ Liv. Garnier, 1913. vol. 1, p. 35-38. Nos livros de Lamego e Feydit encontram-se dezenas de documentos transcritos. Como foram originalmente publicadas no início do século XX, as obras não apresentam o necessário rigor das transcrições de fontes exigido atualmente. Por esta razão, preferi fazer referência aos livros do que às fontes aí transcritas. Vale também mencionar que não encontrei os originais de várias fontes publicadas nestas obras.

22 FEYDIT, Julio. Op. Cit., p. 34-35; PENNA, Patrícia L. Benta Pereira: mulher, rebelião e família em Campos dos Goytacazes, 1748. Dissertação (Mestrado em História), UFF, Niterói, 2014. p. 28-29.

23 BOXER, Charles. Op. Cit., p. 299-300. 
ção, Salvador Correia deixou parte de suas terras sob a custódia dos jesuítas. Os padres da Companhia de Jesus buscaram desenvolver as fazendas e, com ajuda dos beneditinos, construíram uma capela sem contar com os recursos do governador. Alegando o investimento, eles resistiram quando tiveram de devolver as propriedades ${ }^{24}$.

Depois de pacificada a região e redistribuídas as sesmarias, os beneditinos tiveram seu patrimônio rapidamente ampliado, embora suas terras por muito tempo se tornassem motivo de litígios nos Campos dos Goytacazes ${ }^{25}$. Segundo denúncias registradas no Livro de Vereações, os representantes da Ordem de São Bento multiplicavam seus bens ao invadir terras, remarcar e roubar animais. Nem mesmo os viscondes escaparam da sanha dos frades, pois o escrivão e o meirinho, a "requerimento dos Patriarcas Sam Bento", tomaram posse do sítio pertencente à viscondessa de Asseca. Para tanto, não apresentaram documentos ao procurador do donatário, tampouco outro título comprobatório da posse legal das terras. Na câmara, o reverendo frei Plácido Bautista recebeu a acusação de remarcar o gado vacum e cavalos para se apropriar de animais dos moradores, "sem nenhum temor de Deus nem das justiças de Sua Majestade". À época, a excomunhão era estratégia dos beneditinos para enfraquecer a reação dos opositores. Os oficiais da câmara enfrentaram essas ameaças ao tentar coibir os frades e seu controle criminoso de propriedades alheias ${ }^{26}$.

O terceiro visconde denunciou igualmente o desmando dos religiosos que, armados, roubavam escravos e fazendas dos moradores. Para o fidalgo, os beneditinos eram os verdadeiros senhores daqueles campos $^{27}$. Enfim, nos registros camarários, os roubos e as disputas por terras tornaram-se intensos na segunda metade do século XVII, quando a monarquia cedeu aos Correia de Sá a donataria da Paraíba do

24 HARISSON, William. Op. Cit., p. 71-72.

25 SOUZA, Jorge V. A. Para além do claustro, uma história social da inserção beneditina na América portuguesa. Niterói: Editora da UFF/Faperj, 2014. p. 217.

${ }^{26}$ FEYDIT, Julio. Op. Cit., p. 69-86.

27 AHU, Rio de Janeiro, avulsos, doc. 477. 
Sul. A decisão real, por certo, trouxe mais um potente elemento de desintegração dos campos ao invés de promover a harmonia, a prosperidade e o crescimento dos dízimos.

Os conquistadores - os sete capitães - pacificaram a terra, lutaram contra os franceses e seus aliados tamoios e tupinambás, mas viram suas posses ameaçadas pela redistribuição de sesmarias e pela concessão régia que legou ao visconde, em 1674, os vastos campos como capitania hereditária ${ }^{28}$. Assim, geravam-se as desavenças, formava-se o bando com os descendentes dos sete capitães, os beneditinos e jesuítas contra a família Correia de Sá.

Aliás, a notícia da doação da capitania causou grande descontentamento entre os primeiros povoadores e sesmeiros. Juntos com os oficiais da câmara do Rio de Janeiro, os potentados locais tentaram embargar a mercê régia que ameaçava suas propriedades. Alegavam deter a posse das terras por títulos legítimos, originados da doação ocorrida após o abandono da capitania pelo donatário Gil de Góes. Prevendo tempos ruins, os donatários se valeram de garantias concedidas pelo Conselho Ultramarino e alcançaram a autonomia da capitania em relação ao governador do Rio de Janeiro ${ }^{29}$. No ano seguinte, os embargos à doação foram julgados, e o ouvidor geral do Rio de Janeiro determinou a fundação das vilas, conforme estavam previstas na mercê ao visconde e a seu irmão. Como condição para executar a mercê, era preciso fazer medições e demarcações para não provocar prejuízos das áreas de sesmarias preexistentes. Assim, segundo a chancelaria de d. Afonso VI, os donatários não podiam subtrair as terras distribuídas antes do estabelecimento da capitania hereditária.

$\mathrm{O}$ visconde requereu ao rei a patente de capitão-mor e governador da capitania e indicou como loco-tenente Martim Correia Vasqueanes. Dispondo desta mercê régia, o capitão podia fundar vilas, descobrir minas e nomear alcaides-mores. Deveria ainda agir como

2 SALDANHA, António. Op. Cit., p. 95-104.

29 LAMEGO, Alberto. Op. Cit., vol. 2, p. 124-125. 
representante dos donatários para cumprir as exigências expressas na doação ${ }^{30}$. O procurador da Coroa refutou o pedido baseado no descumprimento da norma, pois antes de levantar as povoações e demarcar as terras não deveria existir governador com jurisdição. No entanto, o Conselho Ultramarino entendeu a impossibilidade da presença dos donatários, a ausência do visconde de Asseca e do general João Correia de Sá, e nomeou Vasqueanes como capitão-mor e governador das capitanias. Vale ainda destacar que, a esta altura, a capitania estava subordinada ao governador geral do Brasil e não ao governador do Rio de Janeiro. Ficou ainda estabelecido que os ouvidores nomeados para as capitanias acumulariam a função de feitores da Fazenda Real. A dupla função também valia para o escrivão da câmara e da Fazenda, pois as novas capitanias não apresentavam condições para sustentar tantos ministros ${ }^{31}$.

Em 1674, ao conceder a capitania aos Asseca com o posto de capitão-mor e governador, a monarquia cedeu poder a uma autoridade para governar os moradores, sesmeiros e ordens religiosas. Embora ficasse explícita a preservação das antigas sesmarias, os donatários teriam domínio sobre moendas de água, marinhas de sal e engenhos. Cobravam dízimos, indicavam ouvidores, loco-tenentes e mantinham enorme controle sobre os oficiais da única câmara. Esses poderes constavam da doação e eram parte da jurisdição legada ao donatário, exceto o controle sobre a câmara ${ }^{32}$. No entanto, os registros referentes a Paraíba do Sul fornecem inúmeros testemunhos da destituição de juízes e vereadores ao sabor das conjunturas. Na vila de São Salvador, os oficiais camarários se alternavam segundo o predomínio dos bandos ${ }^{33}$.

30 LAMEGO, Alberto. Op. Cit., vol. 2, p. 134-5.

31 Ibidem, vol. 2, p. 137.

32 AHU, Rio de Janeiro, CA, doc. 13.317. Sobre os domínios senhoriais em Portugal no século XVIII, ver: MONTEIRO, Nuno G. M. O crepúsculo dos grandes. A casa e o patrimônio da aristocracia em Portugal - 1750-1832. Lisboa: Imprensa Casa da Moeda, 1998. p. 461-492. Vale mencionar os amplos poderes senhoriais cedidos aos Asseca quando comparados aos existentes em Portugal setecentista.

33 W. Harrison também mencionou a fragilidade política da câmara; ver: HARRISON, William. Op. Cit., p. 113-115. Sobre as disputas políticas das câmaras e os oficiais régios, ver: RAMINELLI, 
Com a doação da capitania, os sesmeiros e os fazendeiros de gado perderam a autonomia ao se subordinarem ao donatário. Antes, sofriam com as investidas esporádicas das autoridades do Rio, quando o governador distribui sesmarias ou quando os vereadores e governadores investiam na pecuária dos campos abandonados por Gil de Góis. Longe de Lisboa, a expansão das fazendas talvez fosse muito além das sesmarias e engrossasse o patrimônio das ordens religiosas, dos capitães e seus descendentes. Por outro lado, como a capitania não estava demarcada, os proprietários de terras temiam por seus bens e consideravam a possibilidade de suas glebas serem doadas como sesmarias ou roubadas pelo bando do visconde. Assim, os conflitos entre donatários e elites locais estavam centrados em interesses divergentes. De fato, os privilégios gerados pela doação régia contrariavam as elites locais e as ordens religiosas.

Como os demais governadores, o capitão donatário prestava obediência ao governo geral em Salvador e não estava, em princípio, sob a jurisdição do governo do Rio de Janeiro ${ }^{34}$. No entanto, a "nobreza da terra" do Rio de Janeiro via os Campos dos Goytacazes como fronteiras abertas, potencialmente capazes de servir a seus intentos de acumular patrimônio e expandir suas fazendas. Aliás, não somente os proprietários de engenhos almejavam essa meta, os edis e os governadores do Rio de Janeiro, vez por outra, lançavam seus tentáculos em direção ao norte. Tentativas de barrar a posse do donatário não faltaram, mas os locais lutavam contra um grupo influente no Rio de Janeiro e em Lisboa, estribado nos feitos e honras de Salvador Correia de Sá e Benevides ${ }^{35}$.

Em suma, na segunda metade do século XVII, na capitania da Paraíba do Sul, os conflitos envolviam os sesmeiros, os beneditinos, os forasteiros, os ladrões de gado e os novos donatários. As duas capitanias, divididas entre os Correia de Sá, não se efetivaram porque não se pro-

Ronald. Nobrezas do Novo Mundo. Rio de Janeiro: Ed. FGV, 2015. cap. 2.

34 LAMEGO, Alberto. Op. Cit., vol. 2, p. 127.

35 HARRISON, William. Op. Cit., p. 57. 
moveu a demarcação de terras. A indefinição espacial também ameaçava as sesmarias e provocava apropriações indevidas. No período colonial, as fronteiras frequentemente eram predispostas a conflitos entre os moradores que disputavam o controle de terras e os índios. Entretanto, a situação da capitania da Paraíba do Sul era mais grave porque lá coexistiam os antigos conquistadores, sesmeiros e representantes dos donatários ${ }^{36}$. Assim, seus moradores enfrentavam não somente as invasões indígenas, a destruição das vilas, o roubo de gado e de terras, mas também os limites tênues entre o território jurisdicional da capitania real do Rio de Janeiro e da capitania donatária da Paraíba do Sul.

\section{Conflito e jurisdição}

Na última década do século XVII, as disputas e o abandono da capitania se tornaram críticos, sobretudo depois do falecimento do segundo visconde de Asseca, Salvador Correia de Sá e Benevides (16651678). O sucessor, Diogo Correia de Sá e Benevides (1669-1745), demonstrou pouco interesse pelas terras. Pressionada pelo ouvidor, a câmara de Campos escreveu ao rei para denunciar o péssimo estado da vila, sem cadeia e casa da câmara para promover as reuniões. Ficava evidente que os donatários não cumpriram as metas determinadas na carta de doação. $\mathrm{O}$ visconde escreveu aos oficiais para protestar contra a denúncia e ressaltou a existência de muitas vilas arruinadas, carentes de reforma não somente das terras, mas também do procedimento das pessoas ${ }^{37}$.

A situação não se agravou apenas com o falecimento do segundo visconde e com o descaso do terceiro visconde, mas, sobretudo, com a morte do loco-tenente Vasqueanes, responsável pela administração de um território violento, instável e controlado por bandos. O terceiro visconde decidiu então vender a capitania ao prior Duarte Teixeira Chaves. De fato, não era incomum a alienação de capitanias, mas

36 LAMEGO, Alberto. Op. Cit., vol. 2, p. 56-75.

${ }^{37}$ Ibidem, vol. 2, p. 174. 
era indispensável a prévia autorização régia, pois esses bens, mesmo doados, estavam submetidos à Lei Mental ${ }^{38}$. Sem o alvará de licença, as terras eram tomadas à Coroa e as vendas anuladas ${ }^{39}$.

Em 1709, contrariando as condições da doação ${ }^{40}$, o fidalgo vendeu suas fazendas livres e vinculadas ao morgado, e a capitania e a alcaidaria-mor do Rio de Janeiro ao prior Duarte Teixeira Chaves ${ }^{41}$. Vale mencionar que somente a capitania fora avaliada em $100 \mathrm{mil} \mathrm{cru-}$ zados. Sem autorização régia, o novo proprietário se estabeleceu nas terras do Goytacá e passou a atuar como se fosse o visconde, contando com o apoio da câmara de Campos. Assim, vendeu terras e exerceu todas as jurisdições de donatário ${ }^{42}$.

A primeira providência do prior foi destituir o capitão-mor e alijar do poder os demais oficiais aliados dos Asseca ${ }^{43}$. O ouvidor-geral do Rio de Janeiro, Roberto Carr Ribeiro, acatou as denúncias dos moradores sobre os desmandos do prior e escreveu ao Conselho Ultramarino para recomendar ao rei o sequestro da jurisdição da capitania e o envio do prior Chaves para prisão no Reino ${ }^{44}$. Pela primeira vez, os Asseca perdiam a capitania, e o território voltava à jurisdição régia para o consolo dos moradores.

A mencionada alienação promoveu um triplo abuso de jurisdição. Em princípio era expressamente proibida a venda da capitania, das

38 Ordenações manuelinas, liv. 2, tít. XVII, Da maneira que se há de teer na socessam das Terras, e Bens da Coroa do Reyno. Disponível em: http://wwwl.ci.uc.pt/ihti/proj/manuelinas/l2p66.htm.

39 SALDANHA, António. Op. Cit., p. 122-130; LAMEGO, Alberto. Op. Cit., vol. 2, p. 184-186; FEYDIT, Julio. Op. Cit., p. 89-91.

40 SALDANHA, António. Op. Cit., p. 122-130.

41 AHU, Rio de Janeiro, avulsos, doc. 931. O prior comprou do visconde de Asseca um engenho no Campo Grande em 20.10.1709 no valor de 45 mil cruzados. Arquivo Nacional (AN), 1ON, 81, p. 122v; sítio no valor de 8 mil. AHU, Rio de Janeiro, avulsos, 931; terras no valor de 3 mil cruzados. AN, 2ON, 22, p. 1.

42 Em 1729, o visconde de Asseca ordenou o sequestro de todas as fazendas do morgado vendidas pelo prior; ver: AHU, Rio de Janeiro, CA, doc. 6414-6416.

43 Sobre as intervenções do prior Chaves, ver: LAMEGO, Alberto. Op. Cit., vol. 2, p. 184-186; SALDANHA, António. Op. Cit., p. 128.

${ }^{44}$ AHU, Rio de Janeiro, avulsos, doc. 931. 
fazendas vinculadas e do posto de alcaide-mor. Contrariava a mercê de doação a concessão da jurisdição da capitania ao prior, ou seja, a permissão de controlar a justiça, os dízimos, o provimentos de postos e ofícios, e destituir e nomear o capitão-mor. Para agravar ainda mais a situação, o religioso vendeu as fazendas e as propriedades da capitania. Por volta de 1723, ao tentar reaver a donataria, o terceiro visconde recebeu licença para que seu filho, Martim Correia de Sá, administrasse os bens do Brasil e justificou o episódio protagonizado pelo prior ${ }^{45}$. De fato, ele alegou inocência, pois passou procuração a Duarte Teixeira Chaves para governar a donataria depois da morte de Vaqueanes. Traindo a sua confiança, o prior excedera os poderes e "se intrometera em atos que não eram da sua jurisdição" 46 .

Somente em agosto de 1727, Diogo Correia de Sá recebeu o direito de reincorporação da capitania da Paraíba do Sul, mas a jurisdição do donatário estava reduzida. A punição não se referia à venda indevida e aos apuros provocados pelo prior, mas ao descumprimento das metas estabelecidas na carta de doação original. Em princípio, o procurador da Coroa era favorável à concessão de "todas as jurisdições, rendas, direitos e pertenças concedidas na carta de doação" de $1674^{47}$. Entretanto, o rei e seus procuradores estabeleciam algumas punições: a redução das terras doadas; a exigência de correições promovidas pelos ouvidores reais ${ }^{48}$; os governadores e capitães-mores foram impedidos de enviar anualmente a Portugal 24 escravos resgatados; perda do quinto cobrado na extração de pau-brasil; as condenações de morte natural deveriam ser julgadas pela alçada superior; e somente os transversais do primeiro visconde podiam herdar a mercê $\hat{A}^{49}$. As

\footnotetext{
45 A Consulta do Conselho Ultramarino de maio de 1726 fornece mais informações sobre a tratativa do visconde para retomar a capitania, ver: AHU, Rio de Janeiro, avulsos, doc. 1754.

${ }^{46}$ LAMEGO, Alberto. Op. Cit., vol. 2, p. 200.

${ }^{47}$ Ibidem, vol. 2, p. 204-205.

48 Vale mencionar que esta exigência não é nova. A carta de doação de 1674 mencionou as correições do ouvidor geral quando fossem necessárias; ver: AHU, Rio de Janeiro, CA, doc. 13.317; FEYDIT, Julio. Op. Cit., p. 60.

49 ANTT, Chancelaria de D. João V, liv. 5, f. 50.
} 
restrições impostas talvez tivessem atingido as combalidas finanças da Casa Asseca ${ }^{50}$.

Em fevereiro de 1728, o terceiro visconde de Asseca enviou procuração para conferir a seus filhos, Martim Correia de Sá e Luiz José Correia de Sá, o direito de exercer jurisdição sobre a Paraíba do Sul. Neste documento, o fidalgo enumerou os poderes do donatário segundo a doação original, embora nem sempre acatasse as punições mencionadas. $\mathrm{O}$ documento previa nomeação de pessoas idôneas para os cargos de alcaides-mores e ofícios de justiça: o ouvidor, escrivães, meirinhos, alcaides, escrivães de vara e das câmaras. O donatário nomeava sargentos-mores, capitães e mais oficiais da ordenança dedicados à defesa da terra. Cobrava ainda a redízima de todos os direitos reais. As engenhocas, engenhos de açúcar e de aguardentes estabelecidos precisavam tirar licenças, e os novos estabelecimentos precisavam de autorizações para iniciar o funcionamento. Em relação às câmaras, o visconde concedia o direito de alimpar as pautas dos oficiais servidores das duas câmaras e doar as terras devolutas conforme os trâmites da confirmação das sesmarias. Como se fosse o titular, o procurador atuava junto ao ouvidor e julgava todas as causas criminais e cíveis, "dando apelação a quem diretamente pertencer, a forma de minha doação e foral" "51. O último ponto contraria tanto as restrições impostas na confirmação de 1727 como a carta de doação de 1674, que também colocava limites às sentenças judiciais.

Na Paraíba do Sul, o filho e procurador do donatário, Martim Correia de Sá, o autor das memórias referidas acima, se dirigiu aos oficiais da câmara da vila de São Salvador para alertar sobre a autonomia dos edis em relação ao governador do Rio de Janeiro. Assim, os homens bons não podiam receber suas ordens, salvo quando o rei ordenasse. Do contrário, "ficaria sem efeito a Real doação de S. M. que Deus guarde, e defraudados os privilégios, que o mesmo Senhor

\footnotetext{
50 Para a situação econômica da Casa Asseca, ver: ANTT, Feitos findos, administração de Casas, maço 9 , n. 9 .

51 AHU, Rio de Janeiro, CA, doc. 6887.
} 
expressamente concede ao donatário desta Capitania ou ao seu bastante procurador...". Os oficiais logo enviaram carta para admoestar o governador sobre a autonomia e aproveitaram a oportunidade para recusar o pagamento do donativo dos casamentos reais ${ }^{52}$.

Talvez impulsionado pela insubordinação dos oficiais da câmara da vila de São Salvador, o governador considerou por bem não reconhecer a procuração do visconde. Passados muitos meses da chegada e posse do filho do visconde de Asseca, o governador Luís Vahia Monteiro emitiu carta patente e nomeou o capitão-mor da vila de São Salvador, ou seja, ordenava a reintegração do capitão-mor João Álvares Barreto e a destituição de Manuel Ferreira de Sá, o último provido pelo visconde e respaldado pela câmara.

A iniciativa de Monteiro não estava estribada na carta de doação, tampouco na carta de confirmação de 1727 e se opunha frontalmente à procuração do terceiro visconde de Asseca. Vale então esclarecer a sequência de fatos: a procuração do donatário e a indicação do locotenente datam de 8 de fevereiro de 1728; o Conselho Ultramarino acatou o pedido de provisão do filho primogênito para administrar a capitania em março de 1729; a nomeação do novo capitão-mor feita pelo governador era posterior, 27 de maio de $1729^{53}$. Aliás, mesmo sabendo do nome indicado pelos Asseca, o governador defendeu seus intentos e indicou um aliado para se opor ao donatário. Acirrava-se assim a disputa, impulsionada tanto pelo conflito de jurisdição como por abuso da jurisdição. Para desvendar esse imbróglio, analiso a conjuntura sob três perspectivas: o suporte régio para apoiar as intervenções do governador; os desmandos do donatário e de seus procuradores; os interesses pecuniários do governador e de seus aliados.

Neste episódio, o governador do Rio de Janeiro comportava-se como se a capitania da Paraíba do Sul fosse subordinada à sua juris-

AHU, Rio de Janeiro, CA, doc. 6887 e 6891.

53 ANTT, Chancelaria de D. João V, liv. 5, f. 50; AHU, Rio de Janeiro, avulsos, doc. 2068. Sobre a disputa entre dezembro de 1728 e abril de 1729, ver: AHU, Rio de Janeiro, CA, doc. 6.890-98. 
dição e não ao governador-geral em Salvador ${ }^{54}$. Monteiro partiu do pressuposto da nulidade da procuração do visconde de Asseca e assim negava a autoridade do seu filho baseado na falta do alvará régio que deveria acompanhar a procuração. Por certo o procurador deveria ser provido pelo monarca, conforme a tradição de controle do processo de escolha e nomeação dos oficiais régios ${ }^{55}$. Para prover o loco-tenente, Luís Vahia Monteiro ainda se valia de uma ordem régia, datada de 10 de setembro de 1704. A norma concedia ao governador do Rio de Janeiro o poder de lançar residência (investigar) os capitães-mores dos donatários e de provê-los quando os donatários não os tivessem nome$\operatorname{ado}^{56}$. Em suma, a monarquia concedia a doação da capitania, com amplos poderes, e ao mesmo tempo recorria ao governador da capitania vizinha para cercear, vigiar e coibir o donatário. Isto era promover conflito de jurisdição.

A ambiguidade da administração central ainda se evidencia nos registros da carta de doação da capitania da Paraíba do Sul. No Rio de Janeiro, em junho de 1728, o governador recebeu a carta e determinou o cumprimento das ordens de sua majestade. Para tanto mandou registrá-la nos livros da secretaria. Aliás, o ouvidor-geral d. Manuel da Costa Mimoso, o provedor da Fazenda Bartolomeu de Siqueira Cordovil e a câmara do Rio de Janeiro também registraram a carta ${ }^{57}$. Estaria então o donatário subordinado ao governador, ao ouvidor-geral, ao provedor da Fazenda e à câmara do Rio de Janeiro? Mais uma vez percebe-se que esta formalidade não estava respaldada nas carta

54 A tese de Luciana Velez sobre a capitania de Itamaracá analisa os conflitos e abusos de jurisdição envolvendo os donatários e seus procuradores, governadores de Pernambuco e os ouvidores da Paraíba; ver: BARBALHO VELEZ, Luciana C. Donatários e administração colonial; a capitania de Itamaracá e a Casa de Cascais (1692-1763). Tese (Doutorado em História), UFF, Niterói, 2016. p. 254-306. Os conflitos entre a câmara de Belém e o donatário da capitania de Cametá se vinculavam ao controle dos índios. PELEGRINO, Alexandre de C. Donatários e poderes locais no Maranhão setecentista (1621-1701). Dissertação (Mestrado em História), PPGH-UFF, Niterói, 2015. p. 90-92.

55 LAMEGO, Alberto. Op. Cit., vol. 2, p. 303-304; SALDANHA, António. Op. Cit., p. 170-171.

${ }^{56}$ AHU, Rio de Janeiro, CA, doc. 6898.

${ }^{57}$ LAMEGO, Alberto. Op. Cit., p. 207, 238 e 245. 
de doação e na sua confirmação de 1727, exceto as correições realizadas pelo ouvidor-geral. Seria um abuso de jurisdição? Aliás, mesmo após os registros, o governador considerou nula tanto a procuração do visconde quanto a provisão do loco-tenente e dos demais oficiais.

Ao cumprir sua função, o ouvidor-geral, em carta ao provedor da Fazenda, narrou a correição à jurisdição do visconde e de seus capitães-mores. Ao contrário do governador, ele asseverou o cumprimento das normas e o respeito às determinações da carta de doação. Em relação aos rendimentos, o magistrado afirmou que não poderia verificá -los, pois o donatário não pusera em prática a arrecadação de direitos conforme a doação régia ${ }^{58}$. Aliás, Harrison considerou o magistrado um aliado dos Asseca, sobretudo quando ele visitou a capitania e anulou o contrato do gado ao vento, que permitia a captura de escravos e animais soltos e sem a marca do proprietário, conforme a provisão régia datada de 2 de junho de $1728^{59}$.

Antes, Vahia Monteiro denunciou ao rei a violação da carta de doação, pois o filho do visconde estabeleceu, ao arrepio da norma, sentenças judiciais, interferiu na câmara, proveu oficiais das ordenanças, criou registros de passagens e impostos sobre boiadas ${ }^{60}$. Para coibir os desmandos, o governador mandou declarar nulos os provimentos dos postos de ordenanças feitos por Martim Correia de Sá. Escreveu carta aos oficiais da câmara da vila de São Salvador para que remetessem cópias de todas as representações dirigidas ao rei e denunciassem as doações de sesmarias realizadas em território fora da jurisdição do donatário ${ }^{61}$. Enfim, na correspondência do governador evidencia-se a nulidade da procuração do donatário, pois não a considerava suficiente o bastante para permitir que Martim Correia provesse os oficios e praticasse atos da exclusiva competência do donatário.

\footnotetext{
58 AHU, Rio de Janeiro, avulsos, doc. 1992.

59 HARRISON, William. Op. Cit., p. 210; FEYDIT, Julio. Op. Cit., p. 106; LAMEGO, Alberto. Op. Cit., p. 330.

60 LAMEGO, Alberto. Op. Cit., vol. 2, p. 292.

61 AHU, Rio de Janeiro, CA, doc. 6900-6902.
} 
Em carta dirigida à câmara de Campos ainda em 1727, Monteiro concebia claramente a Paraíba do Sul como capitania subordinada, pois, mesmo com a doação, segundo o governante, o soberano não renunciava à suprema e real autoridade sobre os seus domínios. Por esta razão, os governadores da capitania do Rio de Janeiro deviam sempre governar sua capitania anexa ${ }^{62}$. Em fevereiro de 1730, Monteiro retornou ao tema da subordinação e enviou aos oficiais uma cópia da ordem régia de 24 de setembro de 1729, expedida pelo Conselho Ultramarino, assinada pelo secretário da capitania do Rio de Janeiro, para lançar nos livros da câmara da vila de São Salvador. A ordem estabelecia "que sempre este governo [do Rio de Janeiro] tem domínio superior nessa Capitania" $"$.

Em suma, a capitania da Paraíba do Sul estava subordinada ao governo da capitania do Rio de Janeiro, e a Coroa não parecia contrariada com as intervenções do governador ${ }^{64}$. As tratativas contra $o$ donatário eram bem vindas e elogiadas, evidenciando o jogo duplo da monarquia. Mais uma vez, evidencia-se a prática de conceder mercê com amplos poderes, mas incentivar as autoridades coloniais a cercear os direitos e, em parte, a governar a capitania donatária juntamente com o ouvidor-geral e o provedor da Fazenda.

A autoridade do governador tornou-se ainda mais patente quando exigiu que o filho do visconde lhe prestasse juramento de fidelidade em julho de 1729. No palácio e residência do governador Luís Vahia Monteiro, o filho primogênito e procurador do visconde de Asseca fez preito e homenagem pela capitania dos Campos dos Goytacazes. E assim o governador o proveu ao posto de capitão-mor da capitania. Para tanto, se ajoelhou e juntou suas mãos às do governador sobre o missal dos Santos Evangelhos e disse:

62 LAMEGO, Alberto. Op. Cit., vol. 2, p. 280; FEYDIT, Julio. Op. Cit., p. 92-93.

63 A câmara da vila denunciou ao rei os conflitos de jurisdição; ver: AHU, Rio de Janeiro, avulsos, doc. 2033; AHU, Rio de Janeiro, CA, doc. 6904. Ainda não encontrei a mencionada ordem régia.

64 AHU, Rio de Janeiro, CA, doc. 6903. 
Eu Martim Correia de Sá, faço preito e homenagem a Sua Majestade e a vossa Senhoria, em seu nome, como seu governador destas capitanias pela Sua Majestade me tem hora feito mercê, para que a tenha, guarde e governe pelo dito Senhor, ao qual acolherei na dita Capitania ${ }^{65}$.

A cerimônia expressava simbolicamente as relações assimétricas entre o governador e o loco-tenente/filho do visconde, estabelecia ainda o governador como alter ego do monarca e deturpava a hierarquia entre os governadores de capitanias e o vice-rei do Estado do Brasil, à época Vasco Fernandes César de Meneses (1720-1735). Assim, ao invés de a capitania da Paraíba do Sul estar subordinada ao governo geral, vinculava-se como anexa à capitania do Rio de Janeiro. Embora excedesse em demonstrar a subordinação dos Asseca, o governador Vahia Monteiro tinha algum respaldo do Conselho Ultramarino e do monarca. Portanto, o conflito de jurisdições, arquitetado pelo Conselho Ultramarino, concedia amplos poderes de intervenção ao governo do Rio de Janeiro que passou a coibir a autonomia dos irmãos Correia de Sá. Estava então tramado o confisco da capitania como acontecera com Pernambuco logo ao findar a guerra contra os holandeses e com tantas outras no século XVIII ${ }^{66}$.

No entanto, em nome do monarca, o Conselho Ultramarino admoestou o governador por impor a mencionada homenagem. De fato, era recorrente realizar tais cerimônias com os capitães-mores e capitães das ordenanças nas capitanias régias. O juramento de fidelidade era permitido entre o governador e os altos militares das respectivas capitanias, mas constituía um abuso de jurisdição impor essa subordinação aos capitães-mores de capitanias donatárias. $\mathrm{O}$ excesso impetrado pelo

${ }_{65}$ AHU, Rio de Janeiro, CA, doc. 6899. Ver também: FEYDIT, Julio. Op. Cit., p. 93; LAMEGO, Alberto. Op. Cit., vol. 2, p. 321. A carta patente do posto de capitão-mor de Martim Correia de Sá data de 29 de março de 1729, bem anterior à homenagem prestada ao governador; ver: AHU, Rio de Janeiro, CA, doc. 6910.

66 SALDANHA, António. Op. Cit., p. 387-436; ASSIS, Virginia M. A. Palavra de rei: autonomia e subordinação da capitania hereditária de Pernambuco. Tese (Doutorado), Universidade Federal de Pernambuco, Recife, 2001. 
governador denunciava a sua negativa de reconhecer a capitania da Paraíba do Sul como donatária. Aliás, os conselheiros esclareceram, em carta a Vahia Monteiro, a subordinação do donatário ao governo geral e não à capitania do Rio de Janeiro, como asseverava o governador aos oficiais da câmara. Em resposta ao soberano, Monteiro reconheceu que os "donatários não acostumavam dar homenagem (...) e que somente a devia dar nas minhas mãos" depois de autorizado por sua majestade. Enfim, o Conselho Ultramarino admoestou o governador e solicitou obediência às ordens do soberano: “...deveis cumprir inteiramente as cláusulas da doação do Visconde de Asseca"67.

O governador do Rio de Janeiro não atuava só na disputa contra os Asseca. Em vários momentos de 1730, os oficiais da câmara enviaram representações ao rei para denunciar falsificações e violências perpetradas pelo filho do visconde. Inicialmente delataram seu intento de coibir os edis a assinar três folhas em branco para o dito Martim Correia de Sá "lançar sobre as ditas firmas o que lhe parecesse à V. M. em seus nomes, o que eles repugnaram, mas como fossem ameaçados com castigos e degredos, vieram a consentir...". O mencionado capitão-mor coibia ainda muitos moradores, particularmente o capitãomor provido pelo governador e todos os seus parentes.

Contra o visconde também se colocavam "os povos" principalmente os proprietários de engenhos de aguardentes e melaços, pois deviam tributos ao donatário, conforme determinações da carta de doação. Aliás, ameaçavam botar abaixo suas engenhocas para não cumprir a determinação régia. Denunciam ainda conflitos originados das doações de carta de sesmarias. Os sesmeiros estavam ameaçados pela falta de demarcação das terras e pelos conflitos entre o governador e o donatário. De fato, as sesmarias ora eram concedidas por um, ora por

${ }^{67}$ AHU, Rio de Janeiro, avulsos, doc. 2313. Depois desta advertência, Vahia Monteiro escreveu aos oficiais da câmara da vila de São Salvador para reconhecer o donatário. AHU, Rio de Janeiro, CA, doc. 6933. 
outro. O conflito de jurisdição amedrontava os proprietários de terras dos Campos de Goytacazes ${ }^{68}$.

Os oficiais ainda se levantaram contra o donatário recorrendo à carta de doação de 1674, pois os Asseca não construíram igrejas, casas da câmara e cadeia e as 30 casas para os moradores conforme determinação do monarca. Os prédios existentes na vila eram frutos do esforço dos moradores quando a capitania estava subordinada à Coroa: "tudo a custa dos moradores debaixo da proteção da Real Coroa, sem sujeição de qualquer outra pessoa" ${ }^{69}$. Por fim, em carta ao governador, os homens bons da câmara ameaçaram desertar da capitania e a se instalar em capitania régia, ao invés de se submeterem às ameaças, castigos e exploração do donatário ${ }^{70}$.

No auge da crise entre o governador e os Asseca, no fatídico ano de 1730, os oficiais da câmara de Campos escreveram novamente ao rei em nome do povo para prestar homenagem e lembrar dos feitos de guerra que remontavam a seus antepassados. Rogavam pelo salvamento da conquista submetida aos tiranos e prestes a ser destruída. Estavam ameaçados os engenhos, as isenções e liberdades da nobreza da terra que recebiam diferente tratamento, pois não contaram com os privilégios dos cidadãos do Porto. Oprimidos pelos usurários, os moradores se dirigiam às minas, onde teriam melhores oportunidades e fartura de mantimentos. Pediam, enfim, a restauração da capitania e desterro dos opressores. Somente a proteção do soberano era capaz de promover o aumento da capitania ${ }^{71}$.

Martim Correia de Sá reagiu às denúncias dos oficiais da câmara e os ameaçou de prisão, caso não o reconhecessem como capitão-mor e filho do donatário. Neste episódio, mais uma vez ficou demonstrada a fragilidade dos edis. Não raro a câmara da vila de São Salvador era destituída e submetida a novas eleições para alterar a sua composição.

\footnotetext{
68 AHU, Rio de Janeiro, CA, doc. 6919.

${ }_{69}$ AHU, Rio de Janeiro, CA, doc. 6920-26.

70 FEYDIT, Julio. Op. Cit., p. 99.

71 LAMEGO, Alberto. Op. Cit., vol. 2, p. 242-244.
} 
Neste caso, devido ao apoio camarário ao governador, o donatário tramou para enviar à prisão juízes e vereadores ${ }^{72}$. De fato, manteve alguns oficiais presos e remeteu uns poucos a Salvador. Na carta de maio de 1730, encontra-se informação ainda mais valiosa para o debate contra o governador. O capitão-mor se dirigiu aos homens bons:

Tenho entendido que deixando de obedecer-me como devem, na forma das ordens de Sua Majestade, que Deus o guarde, os remeterei presos ao Senhor Vice-rei do Estado a quem está sujeita esta capitania ${ }^{73}$.

Enfim, o conflito de jurisdição entre o governador e o donatário promoveu desordens de todo tipo, como a prisão dos edis, a explícita submissão do capitão-mor ao governador, a retenção do mesmo capitão no Rio de Janeiro e o envio de tropas do governador para a vila de São Salvador para manter os poderes locais sob vigilância. $O$ principal aliado de Martim Correia de Sá escreveu também ao monarca para elucidar os interesses escusos do governador ao incitar a rivalidade. $\mathrm{O}$ capitão-mor Manoel Ferreira de Sá, destituído do governo da capitania pelo governador, considerou como boa a administração da capitania entre setembro de 1727 e março de 1729, ou seja, no decurso deste tempo o filho do donatário não desrespeitou a jurisdição concedida pela Coroa. Mesmo assim, o governador suspendeu a posse do representante do donatário para afastá-lo da vila de São Salvador e facilitar o arrendamento de escravos, gado e cavalgaduras ao vento.

A provisão do gado ao vento talvez fosse a razão para que o governador retrocedesse e não acatasse a procuração do visconde sem o alvará régio. A argumentação do sargento-mor Ferreira de Sá se fortalece quando se constata que o prior Chaves, o mesmo comprador da capitania, era tio de Luís Vahia Monteiro. O prior e o governador eram

72 Sobre os conflitos entre os senhorios e os concelhos em Portugal setecentista ver: NETO, Margarida Sobral. Senhorios e concelhos na época moderna: relações entre dois poderes concorrentes. In: CUNHA, Mafalda S. da; FONSECA, Teresa (ed.). Os municípios no Portugal moderno. Lisboa: Colibri/Cidehus, 2005. p. 149-165.

73 Apud: FEYDIT, Julio. Op. Cit., p. 101. 
do mesmo bando do rendeiro do gado ao vento, Francisco Manhães Barreto $^{74}$. O contrato fora obtido no Rio de Janeiro, embora o contratador fosse natural da vila de São Salvador. Estavam também envolvidos na negociação os dois filhos de Benta Pereira, matriarca e símbolo da resistência aos Asseca ${ }^{75}$. Aliás, os Pereira e Barreto eram os aliados do governador na vila. Os proprietários de gado da capitania estavam ameaçados de perder parte de seu patrimônio porque não era possível marcar todos os animais, sobretudo os mais jovens. A ameaça não poupava nem mesmo os religiosos, pois beneditinos e jesuítas também denunciaram a prática ilícita. Para conter o confisco, os oficiais da câmara decidiram suspender a introdução e o uso do injusto arrendamento, baseados no requerimento feito pelos criadores de gado da capitania ${ }^{76}$.

Após a homenagem, Vahia Monteiro reteve o capitão-mor Martim Correia de Sá e enviou tropas para a vila de São Salvador para enfrentar a rebeldia dos oficiais que se recusavam a aprovar o contrato do gado ao vento. Com 30 soldados, dois sargentos e um alferes rumaram à capitania e lá chegando não encontraram o sargento-mor Manoel Ferreira de Sá e os oficiais da câmara. Os últimos fugiram da vila para evitar a iminente prisão. Com o reforço militar, a tropa do governador empossou o capitão-mor João Alves Barreto, capaz de sustentar o famigerado contrato. Para tanto alteraram a composição da câmara, dominada pela família Manhães Barreto. Os moradores da vila ainda padeceram com a manutenção das tropas, gastos prolongados até fevereiro de $1730^{77}$. Em suma, conforme Ferreira de Sá, as investidas de Vahia Monteiro tinham alguns intentos: o fortalecimento do bando contrário aos Asseca, a destruição da capitania para provocar a volta dos filhos do visconde a Portugal e a incorporação da Paraíba do Sul ao patrimônio régio ${ }^{78}$.

74 LAMEGO, Alberto. Op. Cit., vol. 2, p. 341.

75 PENNA, Patrícia L. Op. Cit.

76 FEYDIT, Julio. Op. Cit., p. 107.

77 AHU, Rio de Janeiro, CA, doc. 6906.

78 FEYDIT, Julio. Op. Cit., p. 111; LAMEGO, Alberto. Op. Cit., vol. 2, p. 330-33; PENNA, Patrícia L. Op. Cit., p. 123. 
Nos primeiros dias de 1730, chegou ao Rio de Janeiro a decisão real responsável por empossar novamente o filho do visconde. Os oficiais da câmara e o capitão-mor João Alves Barreto resistiram à ordem do monarca e não aceitaram o retorno do procurador do donatário. Em carta ao rei, os juízes e vereadores se opuseram ao visconde e ao rendeiro responsável pelo contrato ao vento ${ }^{79}$.

Mais tarde, amparado por tropas, Martim Correia de Sá se estabeleceu, destituiu e expulsou o capitão-mor, e prendeu vários oficiais. Provido pelo donatário, o ouvidor da capitania os enviou para a cadeia e depois para o Tribunal da Relação da Bahia. Em seguida, o mesmo representante da justiça local procedeu à eleição de novos juízes e vereadores, procedimento denunciado pelo ouvidor geral. Em 1751, ao emitir parecer sobre o imbróglio de Campos dos Goytacazes, o conselheiro Rafael Pires Pardinho considerou as ingerências do ouvidor do visconde sobre a câmara como abuso de jurisdição.

Entretanto, na mesma época em Lousã, o duque de Bragança não se limitava a confirmar as listas de cargos de vereadores, pois pessoas ausentes das pautas e indicadas pelo donatário exerceram cargos no município. Por vezes, as intervenções do poder senhorial nas eleições municipais foram consideradas abusivas e provocavam protestos das comunidades reinóis. Mas na literatura consultada, a destituição da câmara não consta como abusos perpetrados pelos donatários ${ }^{80}$. Neste sentido, os episódios dramáticos da câmara da vila de São Salvador eram mesmo excepcionais, conforme o conselheiro Pardinho. Os eventos e os embates jurisdicionais entre o Conselho Ultramarino, governador e donatário incentivaram Martim Correia de Sá a cole-

\footnotetext{
79 AHU, Rio de Janeiro, CA, doc. 6918.

80 AHU, Rio de Janeiro, CA, doc. 14981. Sobre os poderes senhoriais e municipais em Portugal, ver: HESPANHA, A. M. Às vésperas de Leviathan. Lisboa: Almedina, 1994. p. 380-438; NETO, Margarida Sobral. Op. Cit., p. 152; FARRICA, Fátima. Poder sobre as periferias. Lisboa: Colibri/ Cidehus, 2011. p. 17-27; MONTEIRO, Nuno G. M. O crepúsculo dos grandes. Op. Cit., p. 461-492; CUNHA, Mafalda Soares et alii. Corregedores, ouvidores-gerais e ouvidores na comunicação política. In: FRAGOSO, J.; MONTEIRO, N. G. (org.). Um reino e suas repúblicas no Atlântico. Rio de Janeiro: Civilização Brasileira, 2017. p. 335-370.
} 
cionar documentos e redigir vários bandos nem sempre publicados. Esse acervo se encontra manuscrito na Biblioteca Oliveira Lima em Washington e se presta para análise dos eventos políticos nas décadas de 1730 e 1740, tema da próxima investigação ${ }^{81}$.

\section{Conclusão}

Os conflitos e abusos de jurisdição nos conduzem ao tema da soberania, da autoridade jurídica e moral do Estado para fazer e alterar leis, conforme defendeu G. Marshall ${ }^{82}$. Ao abordar os impérios europeus, Lauren Benton concebeu a soberania de forma menos homogênea, sobretudo quando abordou as diferentes formas de controle jurídico, econômico e militar no mundo colonial. Esse controle, por vezes, se restringia a enclaves e a corredores, a fronteiras instáveis. As conquistas e possessões tão heterogêneas estavam submetidas a leis igualmente desiguais, administradas por oficiais régios, militares, chefes nativos, religiosos e comerciantes. Aliás, o domínio fragmentado do território promovia soberanias parciais ou compartilhadas: "Colonial powers found reasons to created semiautonomous spaces that were legally and politically differentiated from closely controlled territories" $"$.

A administração do Império estava baseada em autoridades delegadas, por vezes providas pela monarquia, como o caso dos donatários. Na Paraíba do Sul, estavam lá articulados os interesses não somente da monarquia, mas também dos diversos segmentos sociais, como os indígenas, sesmeiros, capitães e oficiais régios. A soberania régia era o resultado da negociação com grupos muitos distintos. Daí se entende melhor a ambiguidade da Coroa indicada ao longo desta análise.

81 Oliveira Lima Library, códice 90. Livro dos Registros e Regimentos, Rio de Janeiro, 1730.

82 MARSHALL, G. Soberania. In: Dicionário de Ciências Sociais. Rio de Janeiro: FGV/MEC, 1986. p. 1133-1 134. Para a definição clássica de soberania, ver: BODIN, Jean. Les six livres de la Republique. Paris: Chez Jacques du Puys, 1576. p. 124-154

83 BENTON, Lauren. A search for sovereignty; law and geography in European empires. Cambridge: University Press, 2011. p. 2-3. 
Assim, os registros sobre as disputas na Paraíba do Sul nos remetem a tema de maior amplitude, à "quasi-sovereignty" da soberania régia nos territórios remotos. Nos sertões, as hierarquias sociais eram mais instáveis e os fidalgos do reino não se apresentavam com a mesma honra e poder. Lá se multiplicavam os entraves para se controlar súditos e para pactuar e obedecer às autoridades providas pela monarquia. Estavam mais evidentes os fracassos da administração homogênea e a necessidade de se recorrer às políticas múltiplas e nem sempre coerentes da Coroa. A debilidade da soberania resultava nos confrontos entre diferentes qualidades de súditos, nos abusos e nos conflitos de jurisdição.

A distância entre Lisboa e os Campos dos Goytacazes, ou entre a vila de São Salvador e o Rio de Janeiro incentivava, por vezes, a suspensão das leis, facilitava o uso das forças militares e das prisões nem sempre estribadas nas normas. $\mathrm{O}$ controle desigual sobre esse território periférico demonstrava os limites da autoridade imperial. $\mathrm{O}$ Conselho Ultramarino, por vezes, recorreu aos conflitos de jurisdição como estratégia política para incentivar a "interdependência" ${ }^{85}$ entre os oficiais, entre governadores, donatários e ouvidores ${ }^{86}$. Os conselheiros acreditavam que a sobreposição de tarefas e de poderes era arma potente contra as autonomias. Ora apoiavam o donatário, ora o governador, sua ambiguidade era indício de debilidade de sua soberania. Aliás, notícias sobre conflitos e abusos chegavam rapidamente a Lisboa onde os litígios eram extintos ou domesticados. $\mathrm{O}$ "governo a distância" ${ }^{87}$, por certo, estimulava os confrontos entre autoridades locais e diminuía o potencial dos abusos. Tal estratégia nem sempre viabilizou

${ }^{84}$ Sobre a "quase soberania", ver: "Quasi-sovereignty states came to be imagined everywhere as anomalous legal spaces, where the application of imperial law defied easy categorization and seemed even to require the occasional suspension of law". BENTON, Lauren. Op. Cit., p. 227.

85 ELIAS, Norbert. Introdução à Sociologia, trad. Lisboa: Edições 70, 1999. p. 147-172.

86 Vale aqui mencionar o conceito de "system of checks and balances"; ver: PIKE, Frederick. The municipality and the system of checks and balances in Spanish American colonial administration. The Americas, vol. 15, n. 2, p. 139-158, 1958.

87 RAMINELLI, Ronald. Viagens ultramarinas. São Paulo: Alameda, 2008. p. 17-60. 
o fortalecimento da soberania régia, conforme os acontecimentos na Paraíba do Sul.

Os episódios dramáticos da capitania donatária ganham outra inteligibilidade quando se destaca a sua posição estratégica entre o Rio de Janeiro e as Minas. Sua localização não se remete somente ao seu potencial como área criadora de gado e produtora de alimentos para as áreas mineradoras, mas, sobretudo, como rota do contrabando, entre as minas e o litoral. Os sesmeiros e demais moradores da capitania podiam usufruir de sua geografia privilegiada e acumular ilegalmente ou não os lucros advindos da mineração. Essa hipótese não é comprovada na documentação coeva, mas as possibilidades de contravenção constavam na consulta a sua majestade descrita pelo conselheiro Antônio Rodrigues da Costa em 1732. Ademais, a proximidade das minas talvez ativasse os conflitos e os abusos de jurisdição.

De fato, o Conselho Ultramarino estava ciente dos perigos internos e externos que rondavam as conquistas portuguesas na América. Como área mineradora e comercial, o centro-sul do Brasil era a parte mais frágil do Império português, recentemente ameaçada por invasão francesa e instabilidades políticas na capitania da Paraíba do Sul. Por certo, os limites da soberania régia estavam explícitos nas disputas entre os bandos apoiados pelo governador e pelo donatário. A frágil soberania portuguesa dependia, conforme o conselheiro, da "...primeira e principal máxima dos senhores de Portugal, a qual foi sempre tratarem os seus vassalos como pais, e não como senhores; de que nasceu a fidelidade com que os serviram, rompendo por trabalhos e perigos insuportáveis para estenderem o seu império..."88. Na negociação, a monarquia devia contentar tanto os donatários, afinal serviram ao soberano em momento crucial, quanto os moradores e capitães radicados nos Campos dos Goytacazes. Aliás, a Coroa precisava promover a pacificação da capitania, do contrário a maior ameaça à América

${ }^{88}$ COSTA, Antônio Rodrigues da. Consulta do Conselho Ultramarino a S. M. no ano de 1732, feita pelo conselheiro Costa. Revista do Instituto Histórico e Geográfico Brasileiro, tomo 7, p. 475-482, 1845, p. 481. 
portuguesa, a união entre os perigos internos e externos, segundo a consulta de Rodrigues da Costa, podia resultar na perda do território. Os colonos rebeldes podiam se aliar aos franceses e facilitar o controle inimigo de território próximo das minas.

Desde o início da colonização, a concessão de capitanias hereditárias era estratégia da Coroa para dinamizar a conquista e colonização de áreas remotas e inexploradas. Os donatários ainda se responsabilizavam pela difusão da fé, pela construção de igrejas e manutenção dos cultos. Na farta documentação referente à Paraíba do Sul fica evidente o interesse régio no aumento dos dízimos e nas tratativas para controlar os passos dos donatários, loco-tenentes e ouvidores. A mercê de doação era a remuneração de serviços militares prestados ao soberano e pressupunha redução da soberania régia sobre o território. Conceder jurisdição ao donatário significava renúncia parcial do controle administrativo, sobretudo do âmbito da Justiça e da Fazenda.

As potencialidades da capitania vez por outra receberam menção na documentação. Segundo o capitão Leal, lá existiam tantos bois soltos que o contratador de gado ao vento levaria três anos para reuni -los. Com esse manancial, Martim Correia de Sá introduziu um novo tributo a ser pago pelos criadores. Ao deixar a capitania, as boiadas eram taxadas, e as rendas da Casa Asseca engordadas. Nessa passagem, pelas bandas de Macaé, ninguém cruzava sem o passaporte assinado pelo filho do visconde. Com o avançar dos anos, a produção açucareira e de aguardente lentamente aumentou e passou a disputar com o gado, a maior riqueza da Baixada campista. Em 1737, pagavam tributos 34 engenhos enquanto em 1750, ao final do domínio dos Asseca, eram 50 engenhos ${ }^{89}$. O empenho da Casa na manutenção da capitania estava profundamente vinculado às debilidades de suas finanças e à consequente dependência econômica em relação aos seus tributos. Em 1771, bem depois da perda da mercê régia, um terço dos rendimentos da Casa era proveniente do Brasil. Os motivos econômi-

89 LAMEGO, Alberto Ribeiro. O homem e o brejo. Rio de Janeiro: IBGE, 2007. p. 66-76. 
cos ainda explicam a tentativa desesperada de vender a capitania e as fazendas do morgado. A dependência à possessão ultramarina elucida particularmente as motivações para o envio do primogênito, Martim Correia de Sá, e seu irmão para uma região violenta e muito distante de Lisboa. $\mathrm{O}$ visconde colocava em risco a sucessão do título quando expunha seus herdeiros a riscos eminentes. Aliás, os Asseca não eram os únicos a disputar a manutenção de capitanias donatárias, a Casa de Cascais empenhou-se durante décadas para usufruir dos lucros provenientes dos canaviais de Itamaracá, embora lá a violência e os abusos da jurisdição fossem mais tênues ${ }^{90}$.

Em áreas de fronteira, com escassos oficiais régios, os abusos e os conflitos de jurisdição se faziam com maior intensidade. Com ricas terras e plenas de possibilidades, a capitania da Paraíba do Sul era disputada pelos criadores de gado, senhores de engenhos, ordens religiosas, oficiais régios, donatários e seus representantes. As mortes prematuras do primeiro e segundo viscondes atrasaram intervenções mais efetivas e deixaram a Paraíba do Sul ao abandono. A instabilidade provocada pela venda da capitania ao prior Chaves criou o vazio político ainda maior e ampliou as possibilidades de intervenção do governador do Rio de Janeiro. O primogênito Martim Correia de Sá se tornou o primeiro representante da Casa Asseca a se instalar na capitania e a enfrentar de perto seus adversários.

Vahia Monteiro tratou de anexar a capitania donatária à sua jurisdição e submeter o filho do visconde à humilhação de se ajoelhar aos seus pés e jurar lealdade como se fosse um mero plebeu e capitão-mor de uma anexa. O futuro visconde de Asseca permaneceu retido no Rio de Janeiro, sem permissão de assumir as propriedades da sua Casa. A estratégia de Monteiro reforçava o poderio de seus aliados nos campos, sobretudo do rendeiro do gado ao vento e das famílias Pereira e Barreto. Com o suporte do governador e seu tio, o prior Chaves, essas famílias resistiam bravamente ao estabelecimento dos donatários na região.

90 BARBAlHO VELEZ, Luciana C. Op. Cit. 
Sem os Asseca, a justiça era executada pelos juízes da câmara e pelo ouvidor-geral radicado no Rio de Janeiro que, vez por outra, lançava as suas correições. Os oficiais eram recrutados entre a nobreza da terra e passavam a controlar os acórdãos e o comércio local. Ao expulsar os filhos do visconde estavam controladas as perdas com tributos pagos pelos engenhos e engenhocas. Assegurava-se ainda a distribuição das sesmarias entre os seus clientes.

Para governar a distância, a Coroa lançava mão de estratégias nem sempre respaldadas nos documentos oficiais. A intervenção do governador Vahia Monteiro presta-se para avaliar os limites de sua jurisdição sobre a capitania vizinha donatária, embora fosse território historicamente vinculado ao Rio de Janeiro. Os conselheiros do Ultramarino elogiavam a cobrança de donativos e a anulação da procuração do visconde. No entanto, depois dos distúrbios na vila de São Salvador e da representação do visconde, o monarca e o Conselho Ultramarino reconheceram a autonomia da Paraíba do Sul em relação ao Rio de Janeiro.

Os avanços e recuos da soberania régia estão evidentes na correspondência e nas normas referentes à capitania donatária. A Coroa devia, ao mesmo tempo, assegurar a recompensa para seus aliados e avançar com o processo de centralização administrativa. Nem sempre o controle sobre os territórios se harmonizavam com as mercês. Esses pares de opostos originavam o conflito de jurisdição e permitiam a difusão de excessos de toda ordem. No entanto, ao longo da análise, percebe-se a recorrência de abusos, de práticas contrárias aos ditames régios. A sobreposição de poderes fomentava muitas vezes a autonomia, fosse do governador, fosse do donatário. Enfim, para entender os incidentes, reitero a importância de diferenciar os abusos dos conflitos de jurisdição. Classificar as disputas entre autoridades como jurisdicionais não permite ao historiador distinguir entre as tentativas régias de controle a distância e os interesses particulares das autoridades. Há que distinguir entre a política da monarquia e os interesses dos oficiais régios. Nestes episódios, os interesses particulares se mostravam tão robustos que as táticas da monarquia de promover conflitos de jurisdição eram incapazes de domesticar as disputas. A distância de Lisboa e os 
vários agentes em confronto só faziam corroer a soberania régia nos confins da Paraíba do Sul.

\section{Agradecimentos}

Neste artigo, contei com a colaboração de Nuno Monteiro, Alexandre Pelegrino, Mafalda Soares da Cunha, Isabele Mattos, Luciana de Carvalho Barbalho, Giovane Albino e Thiago Krause.

\section{Referências bibliográficas}

ABREU, Maurício de. Geografia histórica do Rio de Faneiro (1502-1700). Rio de Janeiro: Andrea Jakobsson Estúdio e Prefeitura do Rio de Janeiro, 2010. 2 vol.

ACIOLI, Vera Lúcia Costa. Furisdição e conflito: aspectos da administração colonial. Recife: EdUFPE, 1997.

ALENCASTRO, Luiz Felipe. Trato dos viventes: formação do Brasil no Atlântico Sul. São Paulo: Companhia das Letras, 2000.

ASSIS, Virginia M. A. Palavra de rei: autonomia e subordinação da capitania hereditária de Pernambuco. Tese (Doutorado em História), Universidade Federal de Pernambuco, Recife, 2001.

BARBALHO VELEZ, Luciana C. Donatários e administração colonial; a capitania de Itamaracá e a Casa de Cascais (1692-1763). Tese (Doutorado em História), UFF, Niterói, 2016.

BENTON, Lauren. A search for sovereignty; law and geography in European empires. Cambridge University Press, 2011.

BLUTEAU, Raphael. Vocabulario portuguez e latino. Coimbra: Collegio das Artes da Companhia de Jesu, 1728.

BODIN, Jean. Les six livres de la Republique. Paris: Chez Jacques du Puys, 1576.

BOXER, C. R. Salvador de Sá e a luta pelo Brasil e Angola 1602-1686, trad. São Paulo: Companhia Editora Nacional, 1973.

CAETANO, Antônio Filipe P. Entre a sombra e o sol. A revolta da cachaça e a crise política fluminense. Maceió: Ed. Gráfica, 2009.

CARDIM, Pedro. "Administração" e "governo": uma reflexão sobre o vocabulário do Antigo Regime. In: BICALHO, M. F.; FERLINI, V. (org.). 
Modos de governar. São Paulo: Alameda, 2005.

CHAVES JUNIOR, José Inaldo. As capitanias de Pernambuco e a construção dos territórios e das jurisdições na América portuguesa (século XVIII). Tese (Doutorado em História), UFF, Niterói, 2017.

COSTA, Antônio Rodrigues da. Consulta do Conselho Ultramarino a S. M. no ano de 1732, feita pelo conselheiro Costa. Revista do Instituto Histórico e Geográfico Brasileiro, tomo 7, p. 475-482, 1845.

CUNHA, Mafalda Soares et alii. Corregedores, ouvidores-gerais e ouvidores na comunicação política. In: FRAGOSO, J.; MONTEIRO, N. G. (org.). Um reino e suas repúblicas no Atlântico. Rio de Janeiro: Civilização Brasileira, 2017. p. 335-370.

ELIAS, Norbert. Introdução à Sociologia, trad. Lisboa: Edições 70, 1999.

FARIA, Sheila de Castro. A colônia em movimento. Rio de Janeiro: Nova Fronteira, 1998.

FARRICA, Fátima. Poder sobre as periferias. Lisboa: Colibri/Cidehus, 2011.

FEYDIT, Julio. Subsídios para a história dos Campos dos Goytacazes. Rio de Janeiro: Editora Esquilo, 1979.

FRAGOSO, João. A nobreza vive em bandos: a economia política das melhores famílias da terra do Rio de Janeiro, século XVII. Tempo, n. 15, p. 11-36, 2003.

HARRISON, William F. A struggle for land in colonial Brazil. Tese (Doutorado em História), New Mexico University, Novo México, 1970.

HESPANHA, A. M. Às vésperas de Leviathan. Lisboa: Almedina, 1994.

HOMEM, António P. Barbas. Fudex Perfectus; função jurisdicional e estatuto judicial em Portugal, 1640-1820. Lisboa: Almedina, 2003.

LAMEGO, Alberto. A terra goytacá à luz de documentos inéditos. Paris/Bruxelas: L'Édition d'Art/ Liv. Garnier, 1913. 2 vol.

LAMEGO, Alberto Ribeiro. O homem e o brejo. Rio de Janeiro: IBGE, 2007.

LARA, Sílvia H. Campos da violência. Rio de Janeiro: Paz e Terra, 1988.

MARSHALL, G. Soberania. In: Dicionário de Ciências Sociais. Rio de Janeiro: FGV/MEG, 1986.

MONTEIRO, Nuno G. A casa e o patrimônio dos grandes portugueses (1750-1832). Tese (Doutorado em História), Universidade de Lisboa, Lisboa, 1995. 
. O crepúsculo dos grandes. A casa e o patrimônio da aristocracia em Portugal - 1750-1832. Lisboa: Casa da Moeda, 1998.

D. Fosé na sombra de Pombal. Lisboa: Círculo de Leitores, 2008.

NETO, Margarida Sobral. Senhorios e concelhos na época moderna: relações entre dois poderes concorrentes. In: CUNHA, Mafalda S. da; FONSECA, Teresa (ed.). Os municípios no Portugal moderno. Lisboa: Colibri/Cidehus, 2005.

NORTON, Luís. A dinastia dos Sás no Brasil. Lisboa: Agência Geral do Ultramar, 1965. p. 149-166.

ORDENAÇÕES Manuelinas, liv. 2, tít. XVII, Da maneira que se há de teer na socessam das Terras, e Bens da Coroa do Reyno. Disponível em: http://wwwl.ci.uc.pt/ihti/proj/manuelinas/12p66.htm.

PELEGRINO, Alexandre de C. Donatários e poderes locais no Maranhão setecentista (1621-1701). Dissertação (Mestrado em História), PPGH-UFF, Niterói, 2015.

PENNA, Patrícia L. Benta Pereira: mulher, rebelião e família em Campos dos Goytacazes, 1748. Dissertação(Mestrado em História), UFF, Niterói, 2014.

PIKE, Frederick. The municipality and the system of checks and balances in Spanish American colonial administration. The Americas, vol. 15, n. 2, p. 139-158, 1958.

RAMINELLI, Ronald. Viagens ultramarinas. São Paulo: Alameda, 2008. . Nobrezas do Novo Mundo. Rio de Janeiro: Ed. FGV, 2015.

RHEINGANTZ, Carlos G. Primeiras famílias do Rio de Faneiro (séculos XVI e XVII). Rio de Janeiro: Livraria Brasiliana Editora, 1965-1967. vol. 1, p. 394-395.

SALDANHA, António Vasconcelos de. As capitanias do Brasil. Lisboa: GNPCDP, 2001.

SILVA, Antônio de Moraes. Diccionário da língua portuguesa. Lisboa: Typographia Lacerdina, 1813. vol. 2, p. 195.

SOUZA, Jorge V. A. Para além do claustro, uma história social da inserção beneditina na América portuguesa. Niterói: Editora da UFF/Faperj, 2014.

SUBTIL, José. O terremoto politico (1755-1759). Lisboa: UAL, 2007. 
Ronald Raminelli Almanack, Guarulhos, n. 19, p. 167-204, ago. 2018

Os limites da soberania régia: http://dx.doi.org/10.1590/2236-463320181905 a capitania da Paraíba do Sul entre 1727 e 1730 Orcid:https:/ / orcid.org/0000-0002-9779-5457 